\title{
A STUDY ON THE CHROMOSOMAL DIMORPHISM IN PHYLLOBIUS LONGICORNIS ROELOFS (CURCULIONIDAE, COLEOPTERA)
}

\author{
YASUSHI TAKENOUCHI \\ Biological Laboratory, Sapporo College, Hokkaido University of Education \\ Sapporo, Hokkaido 060
}

Received March 4, 1969

In his former paper the author pointed out that Phyllobius longicornis Roelofs, a member of Otiorrhynchinae, had two kinds of karyotypes: the one is represented by $10+\mathrm{Xy}_{\mathrm{p}}$, while the other by $11+\mathrm{Xy}_{\mathrm{p}}$ (Takenouchi 1955). Studies have been going on the chromosomes of this species. This paper reports some results so far obtained.

Material and Methods: Eighty-eight males of Phyllobius longicornis Roelofs were collected in Mt. Moiwa (Sapporo), a bushy area at the back of the Hokuei Middle School (Otaru), and the Nakano Botanical Garden (Otaru), during June of 1963, 1964, and 1965. Testes were fixed in Smith-Kahle's solution. Chromosome slides were made according to Smith's squash method (Smith 1943).

\section{OBSERVATIONS}

It was found that 78 specimens out of 88 males studied here had 11 chromosomes in haploid, and the remaining 10 had 12 chromosomes.

11 chromosome type: No spermatogonial chromosomes were observed. These 78 males had 10 autosomal bivalents and an $\mathrm{Xy}_{\mathrm{p}}$ sex determining bivalent without exception (Figs. 1 and 2). Seriation in size of the chromosomes is gradual. Animals of this type were obtained in all four localities investigated.

12 chromosome type: The spermatogonial metaphase showed 24 chromosomes (Fig. $3)$, three small elements occured in every case studied: one of them is the y-chromosome and the other two are autosomes. All ten males (Nos. 1-10) studied had 11 autosomal bivalents and an $\mathrm{Xy}_{\mathrm{p}}$ sex bivalent (Figs. 4-18). The number of specimens and of cells investigated are shown in Table 1 . In general, the smallest element, an excess chromosome, is detected in the haploid complement. Although it is almost constant in size within each individual, it shows individual variations. For instance, in some animals the size of the smallest element is really small, being smaller than the X-chromosome (Figs. 5, 6, 9, 11, 12), while in other animals it is nearly the same in size as the $\mathrm{X}$ (Figs. 4, 7, 8, 16) or slightly larger (Figs. 10, 13, 14, 15). In every case the smallest chromosome segregates equationally at the first meiotic division, but sometimes it follows to other elements. The animals with such a chromosome constitution were obtained so far only in Mt. Moiwa, Sapporo (Table 2). 


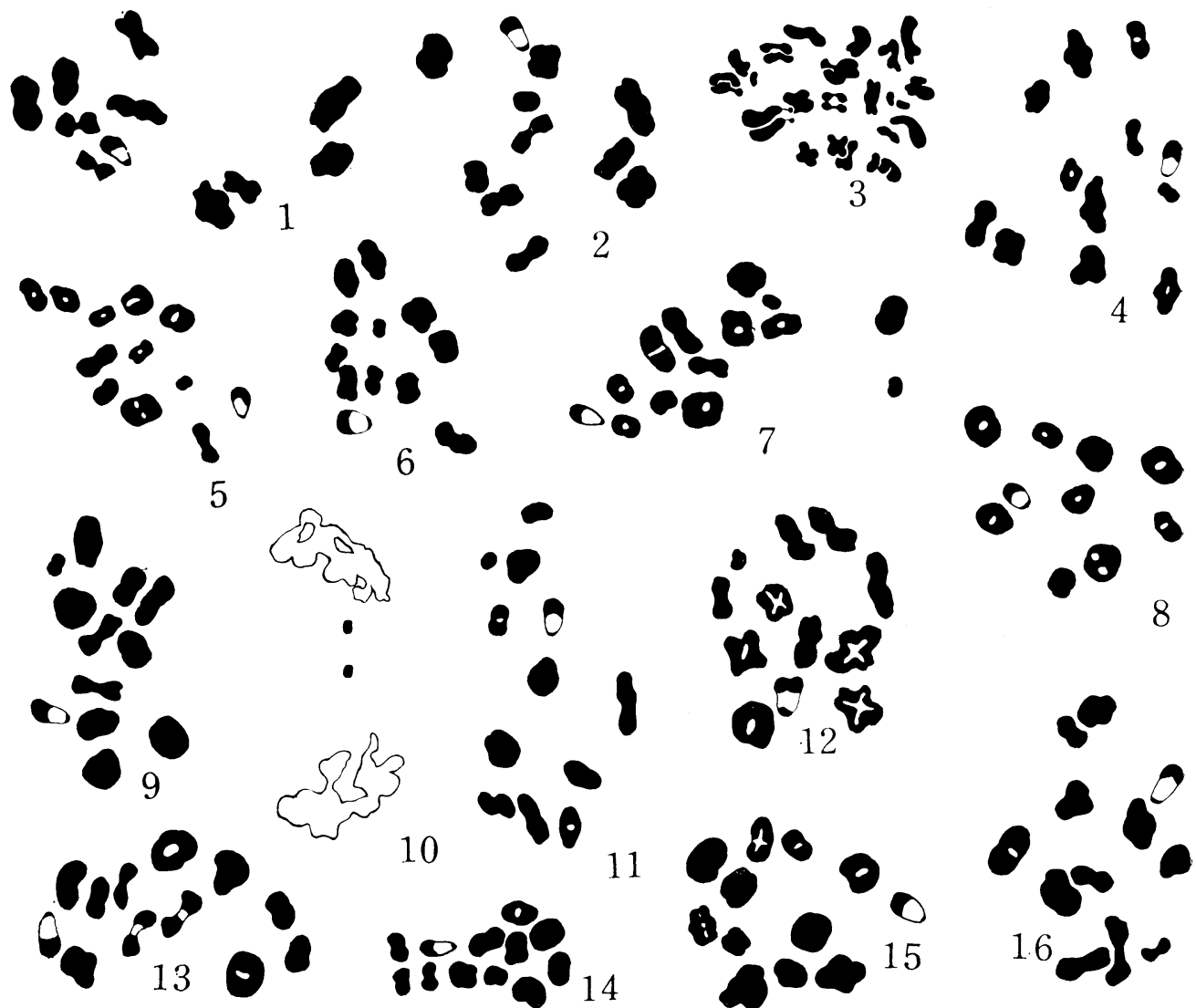

Figs. 1 and 2. First metaphases of the standard 11 chromosome-type of Phyllobius longicornis.

Figs. 3 -16. Chromosomes of the 12 chromosome-type of Phyllobius longicornis. Fig. 3. Spermatogonial metaphase of No. 1. Fig. 4. First metaphase of the same individual (No. 1). Fig. 5. First metaphase of No. 2. Fig. 6. First metaphase of No. 3. Fig. 7. First metaphase of No. 4. Figs. 8-10. Chromosomes of No. 5. Figs. 8 and 9. First metaphases. Fig. 10. Late anaphase of the first division. Fig. 11. metaphase of No. 6. Fig. 12. First metaphase of No. 7. Figs. 13 and 14. First metaphases of No. 8. Fig. 15. First metaphase of No. 9. Fig. 16. First metaphase of No. 10. $(\times 3,600)$
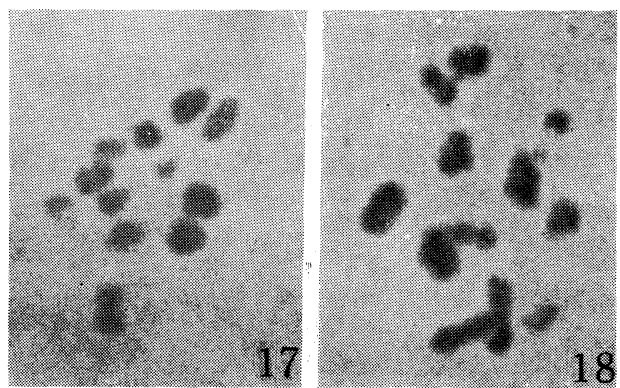

Figs. 17 and 18. Photomicrographs of the first metaphases of the 12 chromosome type of Phyllobius longicornis. Figs. 17 and 18 correspond to Figs. 6 and 16 , respectively. $(\times 3,600)$ 
Table 1. Collection records from three parts of Hokkaido, during June, 1963, 1964, and 1965, and number of specimens with 11 chromosomes or 12 chromosomes

\begin{tabular}{|c|c|c|c|c|c|}
\hline Year & Date & Locality & $\begin{array}{l}\text { No. of } \\
\text { specimens } \\
\text { collected }\end{array}$ & $\begin{array}{c}\text { No. of } \\
\text { with } 11 \\
\text { chromosomes }\end{array}$ & $\begin{array}{c}\text { No. of } \\
\text { with } 12 \\
\text { chromosomes }\end{array}$ \\
\hline 1963 & June 9 & $\begin{array}{l}\text { Back of Hokuei Middle } \\
\text { School (Otaru) }\end{array}$ & 4 & 4 & \\
\hline 1963 & June 12 & Mt. Moiwa (Sapporo) & 9 & 9 & \\
\hline 1963 & June 13 & " & 17 & 15 & 2 \\
\hline 1963 & June 16 & $\begin{array}{l}\text { Nakano Botanical } \\
\text { Garden (Otaru) }\end{array}$ & 4 & 4 & \\
\hline 1964 & June 12 & Mt. Moiwa (Sapporo) & 47 & 39 & 8 \\
\hline 1964 & June 20 & $\begin{array}{l}\text { Nakano Botanical } \\
\text { Garden (Otaru) }\end{array}$ & 2 & 2 & \\
\hline \multirow[t]{2}{*}{1965} & June 28 & $"$ & 4 & 4 & \\
\hline & & Total & 88 & 78 & 10 \\
\hline
\end{tabular}

Table 2. Number of cells with 12 chromosomes in each animal investigated

\begin{tabular}{cc}
\hline \hline Specimen No. & No. of cells with 12 chromosomes \\
No. 1 & 48 \\
No. 2 & 17 \\
No. 3 & 17 \\
No. 4 & 5 \\
No. 5 & 2 \\
No. 6 & 110 \\
No. 7 & 3 \\
No. 8 & 18 \\
No. 9 & 15 \\
No. 10 & 16 \\
\hline
\end{tabular}

\section{DISCUSSION}

In the Curculionidae, Takenouchi (1955) was the first who found that Phyllobius longicornis Roelofs showed two chromosome types: the one had $10+\mathrm{Xy}_{\mathrm{p}}$, while the other $11+\mathrm{Xy}_{\mathrm{p}}$. The same feature was found to occur in four other species of this family: Cryptorrhynchidius lapathi Linne had $16+\mathrm{Xy}_{\mathrm{p}}$ and $17+\mathrm{Xy}_{\mathrm{p}}$ (Takenouchi 1955); Phyllobius rotundicolis Roelofs showed $10+\mathrm{Xy}_{\mathrm{p}}$ and $11+\mathrm{Xy}_{\mathrm{p}}$ (Takenouchi 1958b); and Apoderus jekeli Roelofs had 17+Xy and 18+Xy (Takenouchi 1954, 1955, 1963). Furthermore, he found that Metialma sp.*, which feed on Impatiens noli-tangere Linne, showed three different types: $14+\mathrm{Xy}_{\mathrm{p}}, 15+\mathrm{Xy}_{\mathrm{p}}$ and $16+\mathrm{Xy}_{\mathrm{p}}$ (Takenouchi 1958a). The external

* This species is described as Euryommatus sp. in two papers by Takenouchi (1954, 1958a), but recently it was identified as Metialma sp. by Dr. K. Morimoto. 
features of specimens having two or three different chromosome type are quite similar in every species and indistinguishable from each other.

The present study revealed that in Phyllobius longicornis there were two different chromosome types: the one with $10+\mathrm{Xy}_{\mathrm{p}}$ and the other with $11+\mathrm{Xy}_{\mathrm{p}}$. The species of the genus Phyllobius hitherto studied cytologically are: P. annectenus $(10+\mathrm{Yy})$, $P$. galloisi $\left(10+\mathrm{X}_{\mathrm{p}}\right), \quad P$. longicornis $\left(10+\mathrm{Xy}_{\mathrm{p}}, 11+\mathrm{Xy}_{\mathrm{p}}\right), \quad P$. rotundicolis $\left(10+\mathrm{X}_{\mathrm{p}}\right.$, $\left.11+\mathrm{X}_{\mathrm{p}}\right), \quad P$. brevitarsis $\left(10+\mathrm{X}_{\mathrm{p}}\right), \quad P$. nigritus $\left(10+\mathrm{X}_{\mathrm{p}}\right)$ and $P$. armatus $\left(10+\mathrm{X}_{\mathrm{p}}\right)$ (Takenouchi 1954, 1955, 1958b). Therefore, the standard chromosome number of the genus Phyllobius is $n, 10+\mathrm{Xy}_{\mathrm{p}}$. In P. longicornis the specimens with $11+\mathrm{X}_{\mathrm{p}}$ showed 11.8 per cent in occurrence. Whilst the occurrence of the animals with ordinary formula is 88.2 per cent. As seen in Table 1, the chromosomally unusual animals were obtained only in Mt. Moiwa. It has been shown that in Mt. Moiwa population, 15.6 per cent of the studied specimens were $11+\mathrm{Xy}_{\mathrm{p}}$ males, and 84.4 per cent were $10+\mathrm{Xy}_{\mathrm{p}}$ males. As Virrki (1965) poined out in anthribid beetles, the $11+\mathrm{Xy}_{\mathrm{p}}$ type of $P$. longicornis could have resulted from a centric fusion, although the details have remained for future study. No $10+\mathrm{Xy}_{\mathrm{p}} / 11+\mathrm{Xy}_{\mathrm{p}}$ mosaic male has been observed so far.

\section{SUMMARY}

The chromosomes of Phyllobius longicornis Roelofs collected from three localities in Hokkaido were studied in male germ line. The present species showed two forms which differ in their chromosome number: $10+\mathrm{Xy}_{\mathrm{p}}$ and $11+\mathrm{Xy}_{\mathrm{p}}$. In Mt. Moiwa population, the occurrence of the former form is 84.4 per cent, while that of the latter is 15.6 per cent.

\section{ACKNOWLEDGMENT}

The author is grateful to Prof. S. Makino, Hokkaido University, for improvement of the manuscript.

\section{LITERATURE CITED}

Smith, S. G., 1943 Techniques for the study of insect chromosomes. Can. Entomol. 75: 21-34.

Takenouchi, Y., 1954 Chromosomes of 14 species of the Curculionidae (Coleoptera). J. Hokkaido Gakugei Univ. 2nd Ser. 5: 85-92.

Takenouchi, Y., 1955 A chromosome survey in thirty species of weevils (Curculionidae, Coleoptera). Japan. J. Zool. 11: 425-441.

Takenouchi, Y., 1958a A further chromosome survey in thirty species of the weevils (Curculionidae, Coleoptera). Japan. J. Zool. 12: 139-155.

Takenouchi, Y., 1958b Further survey of the chromosomes in curculionid weevils (Coleoptera). Japan. J. Genet. 33: 163-175.

Takenouchi, Y., 1963 A further investigation on the chromosomes in twenty-three species of weevils (Curculionidae, Coleoptera). J. Hokkaido Gakugei Univ. 2nd Ser. 13: 160-174.

Virrki, N., 1965 Chromosomes of certain anthribid and brentid beetles from El Salvador. Ann. Acad. Sci. Fenn. Ser. A, IV Biol. 83: 4-11. 